A Journal of Agricultural Science Published by the California Agricultural Experiment Station

\title{
SOIL FUMIGATION WITH CHLOROBROMOPROPENE FOR THE CONTROL OF NUTGRASS
}

BOYSIE E. DAY

\section{EFFECT OF 2,4-D UPON THE DEVELOPMENT OF THE COTTON LEAF ERNEST M. GIFFORD, JR.}

This issue completes Volume 21

UNIVERSITY OF CALIFORNIA - BERKELEY, CALIFORNIA 


\section{SOIL FUMIGATION WITH CHLOROBROMOPROPENE FOR THE CONTROL O'F NUTGRASS}

Excised tubers of nutgrass, Cyperus rotundus L., placed in flasks containing either vermiculite or soil, were killed by fumigating with a commercial formulation containing 55 per cent of 1-chloro-3,bromopropene (CBP), added at the rate of $0.04 \mathrm{ml}$ per liter of confined space. Maximum kill was attained after 5 hours' fumigation.

The effectiveness of the fumigant was largely independent of temperature; but soil-moisture content three quarters or more of field capacity restricted movement of $C B P$ vapor through the soil and imparted varying degrees of protection from the fumigant.

Preliminary field trials indicate that 80 gallons of CBP formulation per acre, injected 8 inches deep with a weed gun, may be expected to give effective control of nutgrass infestations on well-tilled soils of moderately low moisture content. Soil compaction limited movement and reduced the effectiveness of the fumigant under field conditions.

\section{EFFECT OF 2,4-D UPON THE DEVELOPMENT OF THE COTTON LEAF}

Cytohistological studies indicate that in the terminal bud of cotton (Gossypium hirsutum L. var. Acala), 2,4-D applied in sublethal dosage to the cotyledons affects the structure and morphology, not of the apical meristem itself, but of the organs and tissues derived from it. 2,4-D affects not only foliage-leaf primordia present at the time of application but also some that develop thereafter.

Treated plants resemble untreated in the structure of the shoot apical meristem (though the dimensions differ) and in the initiation of new foliage leaves. The earliest divisions in the development of the leaf blade appear normal in treated plants. Subsequent ones, however, are precociously and predominantly periclinal, which results in the formation of a thick lamina. In addition to laterally contiguous bundles formed in a manner similar to that in untreated plants, accessory vascular bundles are present in the lamina which develop from derivatives of an extensive adaxial meristem.

A mature leaf contains a large amount of vascular tissue surrounded in general by unspecialized parenchyma. In the shoot, xylem and sievetube elements differentiate in normal directions, but the former are retarded in development and the latter accelerated as compared with those in untreated plants.

In the shoots of untreated plants, the development of the procambium is continuous and acropetal.

The anatomical responses induced by 2,4-D and those caused by other growth-regulating substances are briefly compared. 


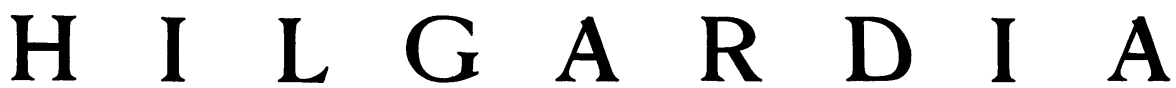

A Journal of Agricultural Science Published by

the California Agricultural Experiment Station

VoL. 21

FEBRUARY, 1953

No. 18

\section{SOIL FUMIGATION WITH CHLOROBROMOPROPENE FOR THE CONTROL OF NUTGRASS ${ }^{1,2}$}

\author{
BOYSIE E. DAY ${ }^{3}$
}

Nutgrass, Cyperus rotundus L., is a perennial sedge which produces tubers (nuts) on creeping rhizomes. The plant is an introduced weed, native to Europe and the tropics, and is believed to have been brought into southern California in the latter part of the nineteenth century. It has become established in irrigated fields and gardens throughout the major agricultural areas of the state. It continues to infest new land, and existing infestations become more firmly established. Because of its extensive rhizome and tuber system, which serves as a means of reproduction and dissemination, it presents a difficult problem in control.

Methods presently available for nutgrass control are expensive in materials or labor and in addition many are of limited effectiveness. Tillage methods are slow and laborious (Davis and Hawkins, 1943 ; Smith and Mayton, 1939, 1942 ; Andrews, 1940a, $b$ ). Smother crops give only partial control (Anonymous, 1938; Holland, 1925; Pollock, 1925; Ranade and Burns, 1925), even when combined with tillage and drying (Davis and Hawkins, 1943). Successful eradication has been reported from flooding for several weeks (Anonymous, 1934; Ranade and Burns, 1925) and from uniform heavy grazing of swine or poultry in small pastures (Mayton, Smith, and King, 1945; Pollock, 1925 ) ; but these methods are not always feasible. Of the insects known to attack nutgrass, none appears promising as a means of effective control (Summerville, 1933).

2,4-D and other growth-regulator herbicides have not been generally successful against nutgrass. Applications of 4 or more pounds per acre kill the tops and reduce subsequent regrowth (Burgis, 1949; Burgis and Spencer, 1947 ; Harrison, 1946 ), particularly with repeated sprayings (Burgis, 1951). But though the basal bulb and adjacent tubers may be killed, outlying tubers survive (Cowart and Ryker, 1950; Harrison, 1946).

A number of soil sterilants have been tested for the eradication of small infestations. Davis and Hawkins (1943) found that sodium chlorate at rates of 320 to 640 pounds per acre, sodium arsenite at 160 pounds per acre, and

\footnotetext{
${ }^{1}$ Received for publication July 8, 1952.

${ }^{2}$ Paper No. 750, University of California Citrus Experiment Station, Riverside, California.

${ }^{8}$ Assistant Plant Physiologist, University of California Citrus Experiment Station, Riverside, California.
} 
borax at 1,280 pounds per acre failed to control nutgrass effectively. Success has been reported with sodium chloride and arsenic compounds (Pollock, 1925 ) and with thiocyanate applied at the rate of 1,400 pounds of $\mathrm{Ca}(\mathrm{CNS})_{2}$ simultaneously with tillage (Fromm, 1942). Fumigation has been reported effective with methyl bromide at the rate of 430 pounds per acre when the vapors were retained in the soil by gasproof covers (Leonard and Harris, $1950 a, b)$, with carbon bisulfide at 4,500 pounds per acre (Ciferri, 1931), and with chloropicrin at 400 to 750 pounds per acre (Godfrey, 1939).

Although there is scarcely any limit to the effort or cost one is justified in expending to eliminate small infestations of nutgrass in the early stages of encroachment on fields, the methods used must be highly effective. The present paper reports preliminary experiments with a soil fumigant believed to offer promise for use as a spot treatment in controlling limited infestations of nutgrass.

\section{LABORATORY EXPERIMENTS}

Methods. The fumigant used in this study was a commercial formulation of brominated and chlorinated $\mathrm{C}_{3}$ hydrocarbons containing about 55 per cent of 1,-chloro-3,bromopropene (CBP)." This material is used as a soil fumigant for the control of nematodes, wireworms, and soil-borne fungi.

Laboratory experiments on the toxicity of CBP to nutgrass as affected by concentration, temperature, and time were done by variations of the following standard procedure, used in this laboratory for investigating the response of nutgrass to a wide variety of halogenated hydrocarbons.

Nutgrass tubers were collected from the field, attached roots and rhizomes were removed, and uniform tubers weighing about 1 gram were selected. Tubers damaged by insects or injured in the process of digging were discarded.

Each toxicity test was made by placing 50 tubers in a 500-ml Erlenmeyer flask and adding 30 grams (about $250 \mathrm{ml}$ ) of horticultural vermiculite. The fumigant was added in liquid form (usually 0.01 to $0.05 \mathrm{ml}$ ) by means of a microburette. The flask was quickly stoppered and the contents were shaken to distribute the tubers throughout the vermiculite. With the exception of experiments in which temperature effects were determined, the flasks were allowed to stand at room temperature $\left(23^{\circ}\right.$ to $\left.25^{\circ} \mathrm{C}\right)$ during fumigation. The tubers were then removed, washed in water, and aerated for 1 hour.

Germination tests were made immediately after aeration. Tubers were planted on thick blotting paper in 10 by $11^{\circ} \mathrm{cm}$ plastic trays and placed in a moist germinator at $30^{\circ} \mathrm{C}$ for 7 days. The cultures were examined and sprouted tubers, having either roots or shoots, were counted. Those not sprouting were found to be discolored internally and to have undergone tissue breakdown; this was indicated by a leaching of brown material, which stained the blotters.

In some tests the flasks were completely filled with soil instead of vermiculite. The soil was air-dry (0.23 per cent moisture) Ramona sandy loam screened free of gravel. The fumigant was injected into the soil at about the center of the flask. Otherwise the procedure was the same as for the vermiculite tests.

\footnotetext{
‘ Formula CBP-55, supplied by Shell Chemical Corporation, San Francisco, California.
} 


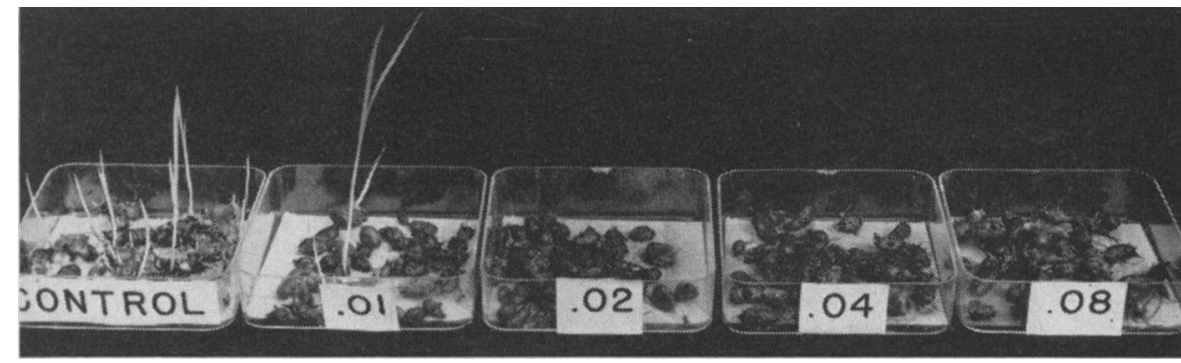

Fig. 1. A determination of the toxicity of the fumigant. Tubers were mixed with vermiculite in $500 \mathrm{ml}$ flasks and fumigated for 18 hours with $.01, .02, .04$, and $.08 \mathrm{ml}$ of CBP formulation. Sprouting tests were then made. The control was not fumigated.

Dosage in Vermiculite. When $0.00,0.01,0.02,0.04$, and $0.08 \mathrm{ml}$ of CBP formulation was added to test flasks containing 50 tubers and 30 grams of vermiculite in the usual manner and fumigated for 18 hours, 41 tubers of the control survived, 5 tubers of the $0.01 \mathrm{ml}$ treatment survived, and all others were killed (fig. 1). The $0.02 \mathrm{ml}$ dosage, which gave a complete kill, is equivalent to $0.04 \mathrm{ml}$ per liter of confined space.

Time of Fumigation. Tubers were fumigated by treatments of $0.00,0.01$, 0.02 , and $0.03 \mathrm{ml}$ of CBP formulation for $1,3,5,8,12,16,20,24$, and 30 hours. Data are shown in Figure 2. The kill was close to maximum in about 5 hours.

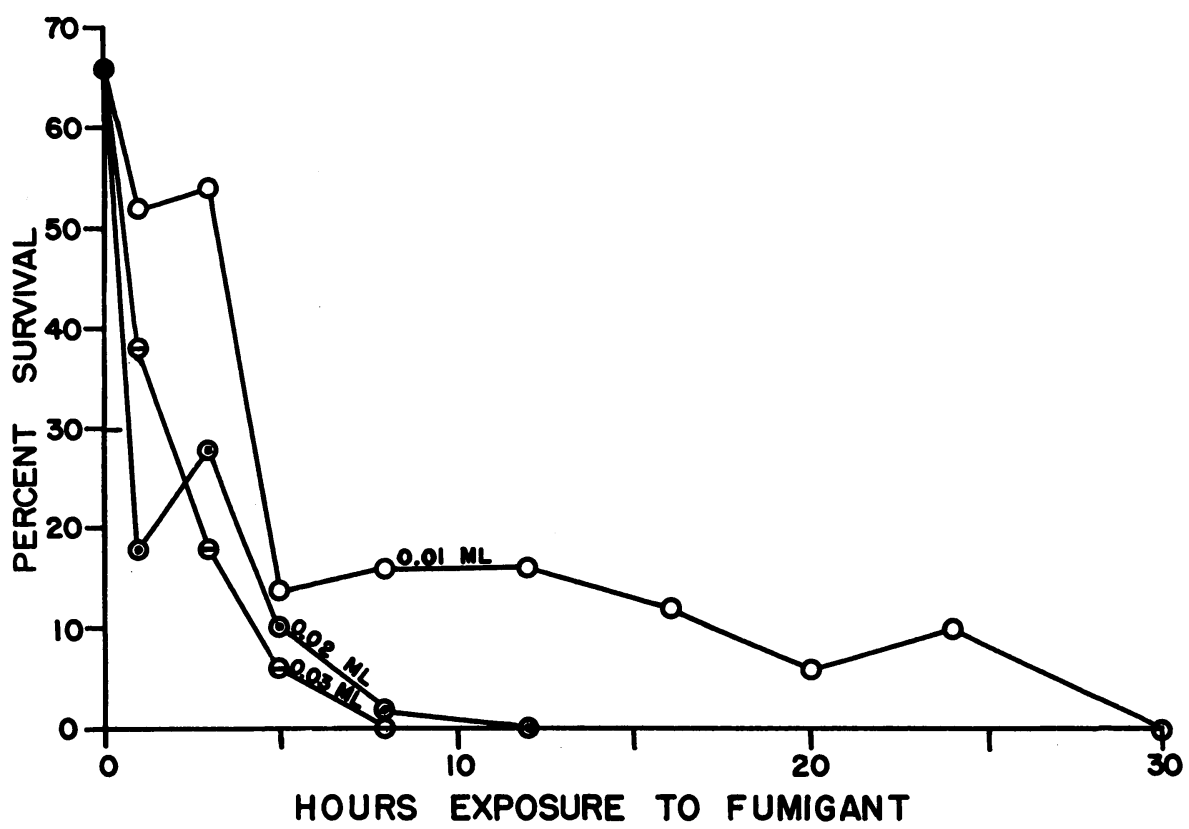

Fig. 2. The effect of length of time of fumigation with different amounts of CBP formulation on survival of tubers. 

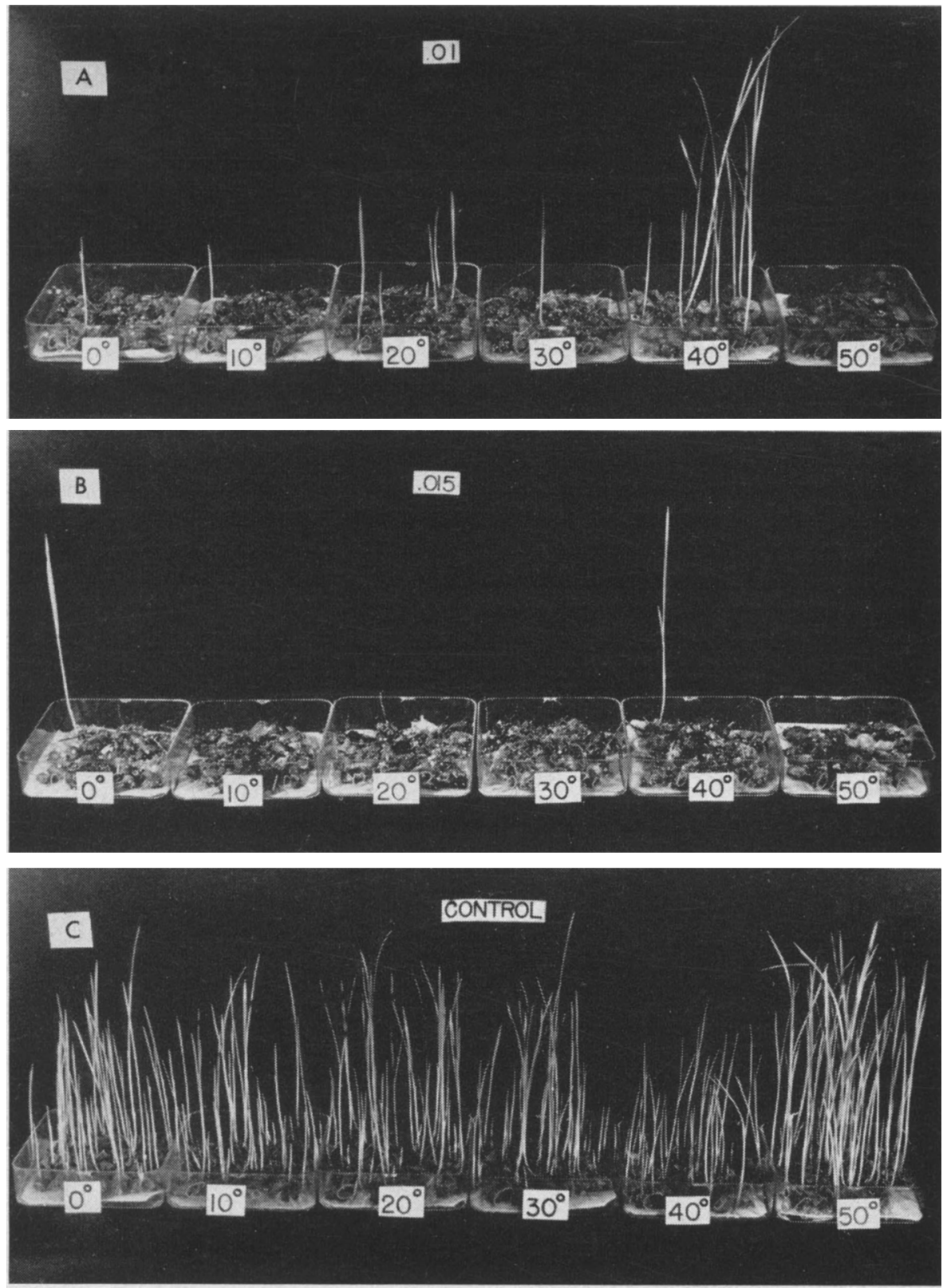

Fig. 3. The effect of temperature during fumigation on the survival of nutgrass tubers treated with: A, $.010 \mathrm{ml}$ of fumigant per $500 \mathrm{ml}$ fumigation chamber. B, $.015 \mathrm{ml}$. C, control (not fumigated). Toxicity of the CBP formulation is largely independent of temperature. 
TABLE 1

PERCENTAGE OF NUTGRASS TUBERS SURVIVING CBP FUMIGATION AT SIX TEMPERATURES

Samples of 50 Tubers Fumigated 18 Hours in 500-ml Flasks of Vermiculite

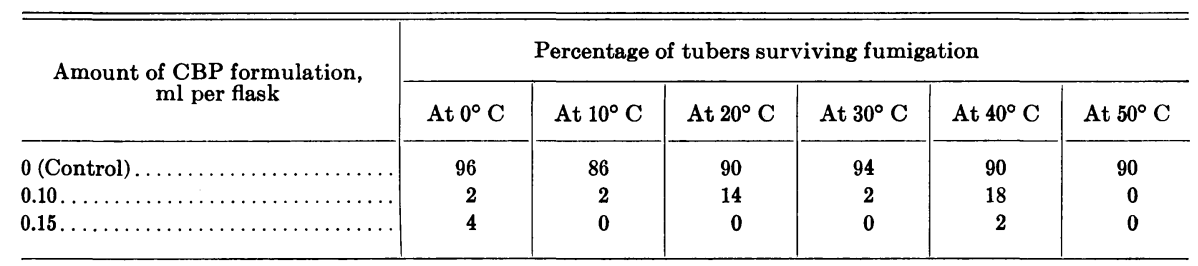

Survival at longer exposures was not closely correlated with time of fumigation, and in some tests was less than at 5 hours.

Temperature. Groups of 50 tubers were fumigated in vermiculite for 18 hours at temperatures of $0^{\circ}, 10^{\circ}, 20^{\circ}, 30^{\circ}, 40^{\circ}$, and $50^{\circ} \mathrm{C}$. At each temperature samples of tubers were treated with $0.00,0.10$, and $0.15 \mathrm{ml}$ of CBP formulation. The results are shown in Table 1 and Figure 3, a photograph

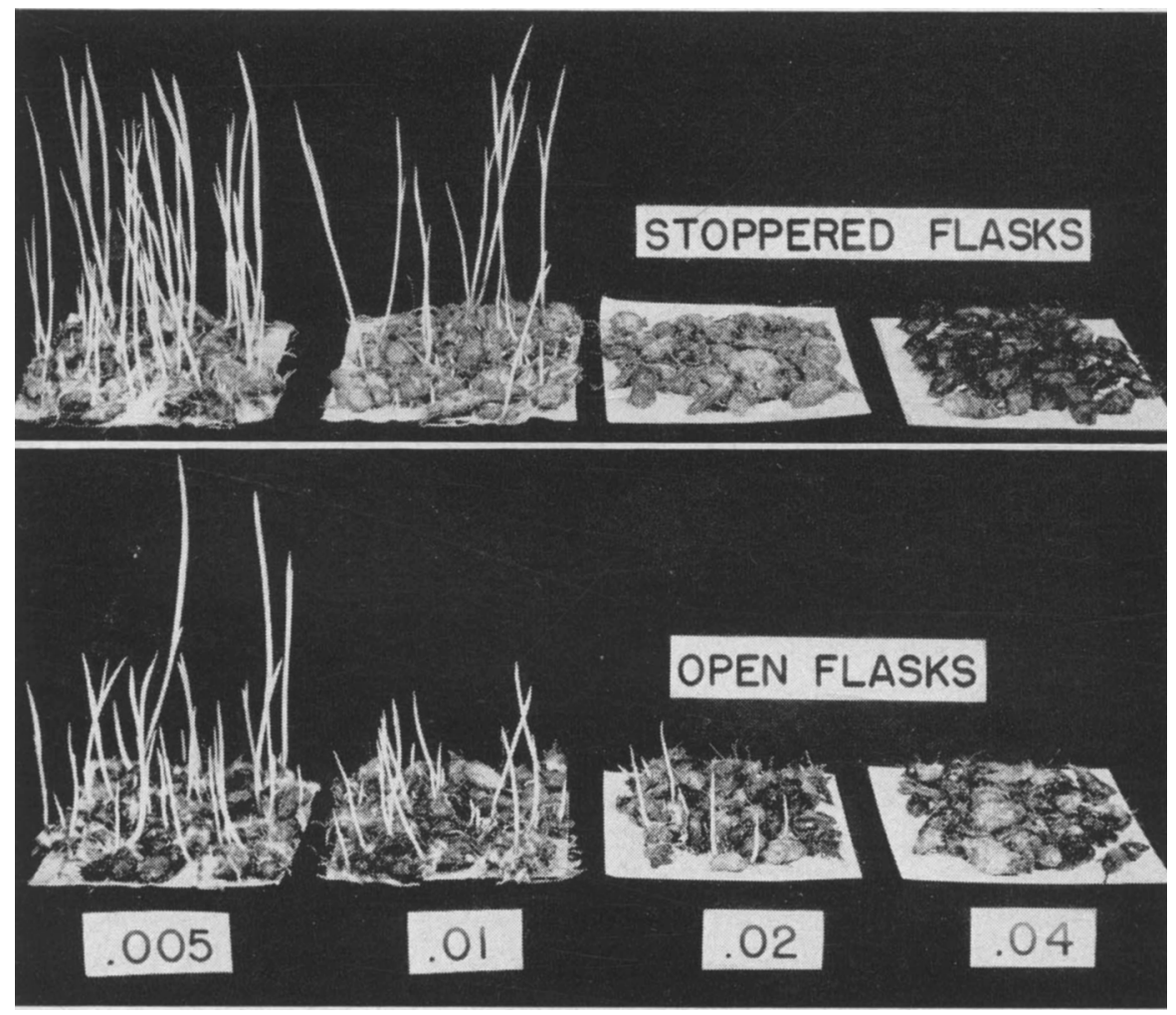

Fig. 4. Retention of CBP vapors in toxic concentrations by soil. Tubers were mixed with soil, placed in $500 \mathrm{ml}$ flasks and fumigated with $0.005,0.01,0.02$, and $0.04 \mathrm{ml}$ of CBP formulation. Survival of tubers was determined in stoppered flasks (above) as compared with open flasks. 
taken at the end of the germination period. Temperature appears to have little influence on the lethal action of the fumigant.

Dosage and Persistence in Soil. To determine the influence of the presence of soil on toxicity and to determine the persistence of CBP in toxic quantities in soils, tests were made with soil in place of vermiculite. Two series of fumigations were carried out, using $0.005,0.01,0.02,0.04$, and $0.08 \mathrm{ml}$ of CBP formulation per flask. The tubers were mixed with the soil in the flasks, after which the soil was injected. In one series the flasks were stoppered, in the other left open. In both, the tubers were fumigated for 18 hours. Results are

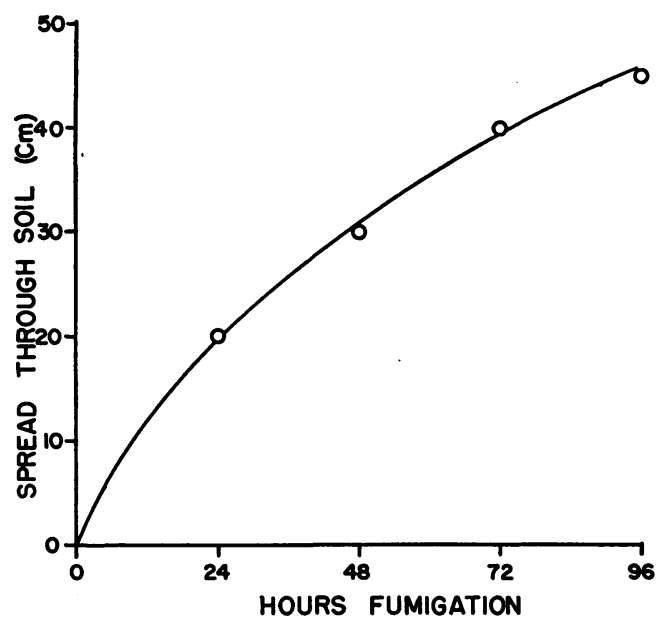

Fig. 5. Fumigant was allowed to diffuse from a saturated vapor through a column of soil containing nutgrass tubers. The extent of spread of the fumigant after various lengths of time is shown.

shown in Figure 4. No tubers survived dosages of 0.04 or higher. Seven tubers-14 per cent-survived in the open containers at $0.02 \mathrm{ml}$ of CBP formulation; however, this experiment demonstrates that even so shallow a depth of soil as that in the flasks will retain CBP vapors long enough to be lethal to nutgrass tubers.

Rate of Spread. Preliminary to field trials, the rate of spread of the lethal effects of CBP formulation through soil was determined.

A cotton plug was placed in the bottom of a 1-meter length of $3-\mathrm{cm}$ glass tubing held vertically on a table, and $10 \mathrm{~cm}$ of Ramona sandy loam soil was tamped into the tube. Ten nutgrass tubers were dropped into the tube, and $5 \mathrm{~cm}$ of soil was packed upon them. More tubers were added, followed by more soil, and this procedure was repeated until 12 groups of tubers had been packed at 5-cm intervals along the tube. A plug of absorbent cotton was placed on top of the uppermost layer of soil, and this was moistened with $1 \mathrm{ml}$ of CBP formulation to provide a surplus of CBP to maintain a saturated vapor. The upper end of the tube was stoppered and the bottom allowed to remain open. 
Four such tubes were prepared, with the CBP formulation added to one of the tubes every 24 hours. After tubes had been fumigated for 24, 48, 72, and 96 hours respectively, all were opened, and viability of the tubers was determined in germinators in the usual way.

The distance to which a lethal amount (100 per cent kill) of fumigant diffused ranged from $20 \mathrm{~cm}$ in the 24-hour treatment to $45 \mathrm{~cm}$ in the 96 -hour treatment (fig. 5).

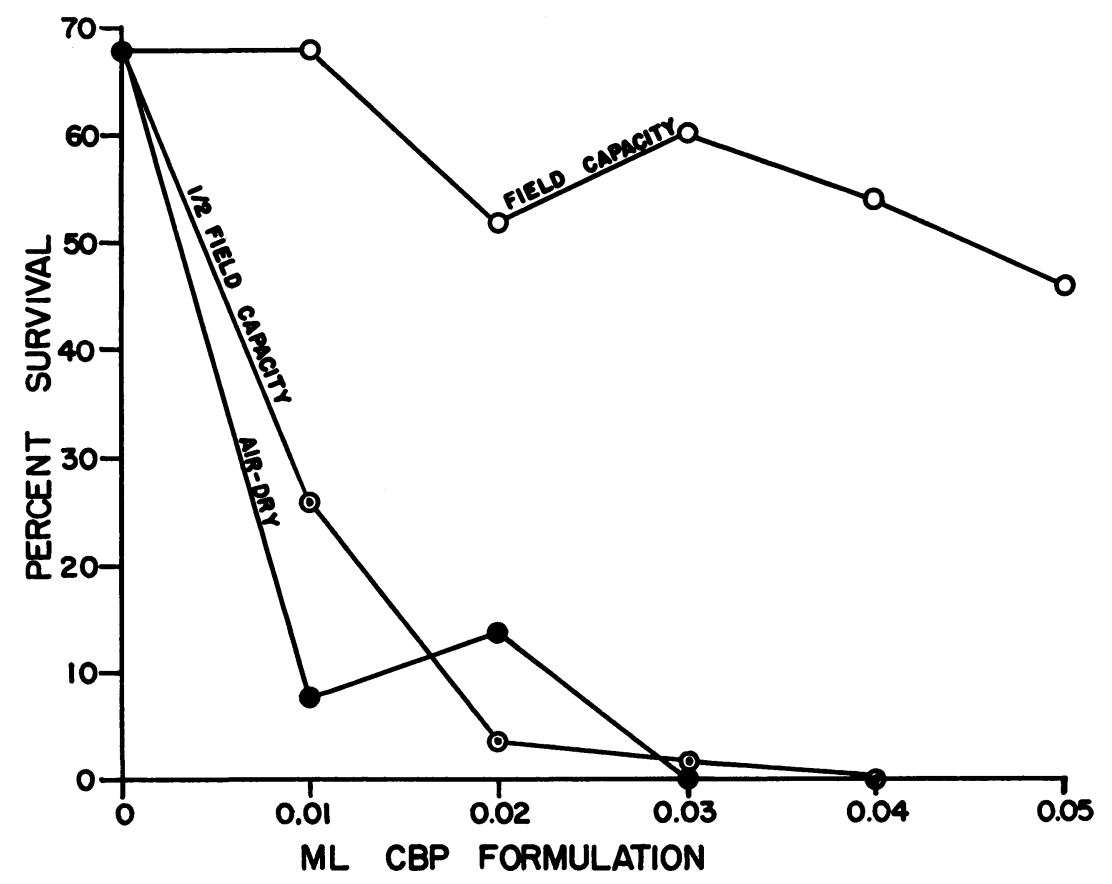

Fig. 6. Germination of tubers after fumigation in soils of three moisture levels contained in $500 \mathrm{ml}$ flasks. Varying amounts of fumigant were injected into the center of the soil mass. Soil at field capacity protected the tubers from high concentrations of CBP.

Soil Moisture. The effect of soil moisture on the action of the fumigant was determined. Fifty nutgrass tubers were mixed with $250 \mathrm{ml}$ of soil containing the following amounts of moisture: 21.4 per cent (field capacity), 10.7 per cent, and 0.23 per cent (air-dry). The soil-tuber samples were placed in 500 $\mathrm{ml}$ flasks. A sample of each soil moisture content was fumigated with 0.01 , $0.02,0.03,0.04$, and $0.05 \mathrm{ml}$ of CBP formulation injected near the center of the soil mass. Flasks were stoppered for 18 hours, after which the nutlets were removed, washed, aerated, and placed in germinators in the usual manner. Results are shown in Figure 6.

There was little difference between survival in dry soil and in soil at one half of field capacity; however, soil at field capacity afforded a high degree of protection against the fumigant. This protection could be due to an interaction between the soil moisture and the active ingredient of the fumigant 
or to a blocking of the pore space of the soil. The fact that increasing the concentration of fumigant did not overcome the protective action of soil moisture indicates that the paths for gaseous diffusion had been blocked. This observation is in agreement with Hagan's (1941) finding that the permeability of soil to $\mathrm{CS}_{2}$ vapor approaches zero not at zero porosity but in a porosity range of 26 to 29 per cent.

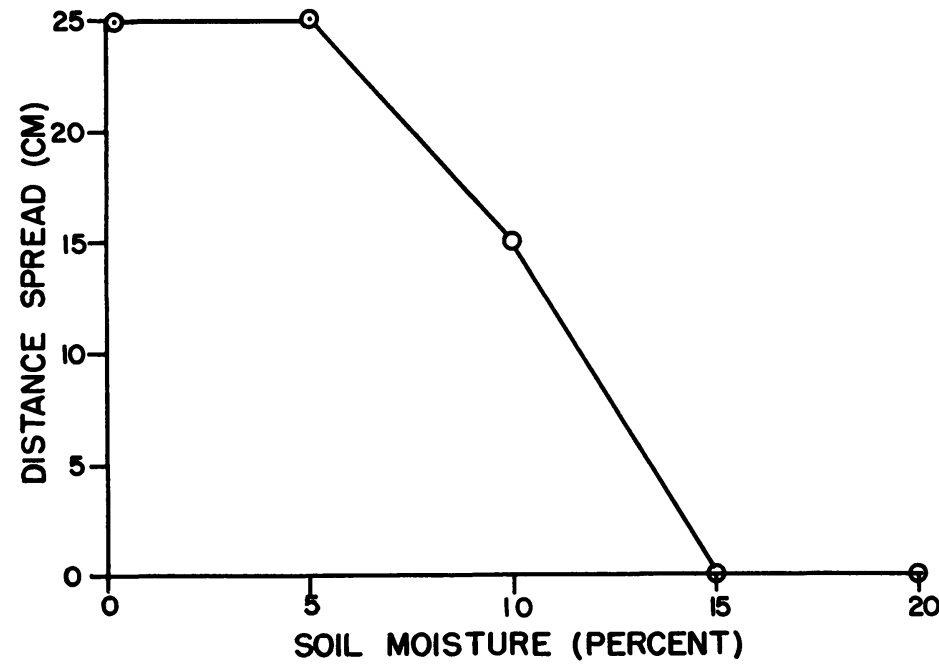

Fig. 7. Effect of soil moisture on distance of movement of soil fumigant during a 48-hour period. Fumigant was permitted to diffuse for 48 hours through soils of different moisture content having groups of nutgrass tubers embedded at 5 - $\mathrm{cm}$ intervals. The distance the fumigant moved is shown.

The effect of soil moisture on diffusion of the fumigant was further investigated by the method used in determining rate of spread. Five glass tubes were filled with soil containing respectively 0.23 (air-dry), 5, 10, 15, and 20 per cent moisture. Samples of 10 tubers were spaced at 5 -cm intervals and fumigant was applied as before. After 48 hours' exposure to the fumigant, tubers were removed and their viability determined. A complete kill of all tubers was attained for 25-cm distance in both the air-dry soil and soil containing 5 per cent moisture (fig. 7). The lethal effect of the fumigant spread $15 \mathrm{~cm}$ through soil containing 10 per cent moisture and less than $5 \mathrm{~cm}$ in soils having 15 and 20 per cent moisture.

Reduction of the porosity of the soil by adding water and by handling it while moist (puddling) accounts for the lack of movement of the fumigant at higher moisture contents. The movement of toxic quantities of CBP is limited by the same factors as that of carbon disulfide (Hagan, 1941; Hannesson, 1945 ; Hannesson, Raynor, and Crafts, 1945). 


\section{FIELD EXPERIMENTS}

Methods. Field experiments were performed near Upland, California, during September and October, 1951. The soil was Hanford fine sandy loam. The portion of the field that was used in tests was covered with a uniform stand of young nutgrass 4 to 8 inches high and having about 6 shoots per square foot. Seedstalks were not present. The soil contained an average of 70 tubers per square foot in the surface 6 inches and 35 per square foot at the 6 to 12 inch depth, as determined by screening out six 2 -square-foot plots. No tubers were found at depths lower than 12 inches in the areas used, although tubers have been found as deep as 22 inches in the same field on other occasions.

TABLE 2

PERCENTAGE OF NUTGRASS TUBERS SURVIVING FIELD TREATMENT WITH CBP FORMULATION AT DIFFERENT RATES

Fumigant Injected to 8-inch Depth with 12-inch Spacing

\begin{tabular}{|c|c|c|c|c|}
\hline \multirow[b]{2}{*}{$\begin{array}{l}\text { Treatment rate, } \\
\text { gallons per acre }\end{array}$} & \multicolumn{2}{|c|}{ In $0-6$ inch depth } & \multicolumn{2}{|c|}{ In $6-12$ inch depth } \\
\hline & $\begin{array}{l}\text { Total } \\
\text { tubers }\end{array}$ & $\begin{array}{l}\text { Per cent } \\
\text { of tubers } \\
\text { surviving }\end{array}$ & $\begin{array}{l}\text { Total } \\
\text { tubers }\end{array}$ & $\begin{array}{l}\text { Per cent } \\
\text { of tubers } \\
\text { surviving }\end{array}$ \\
\hline 0 (Control).. & 113 & 20 & 34 & 35 \\
\hline $10 \ldots \ldots \ldots$ & 344 & 16 & 161 & 50 \\
\hline $20 \ldots \ldots \ldots$ & 124 & 20 & 53 & 32 \\
\hline $40 \ldots$ & 61 & 12 & 34 & 0 \\
\hline $80 \ldots$ & 46 & 7 & 34 & 3 \\
\hline $160 \ldots \ldots$ & 70 & 0 & 36 & 0 \\
\hline
\end{tabular}

CBP formulation was injected 8 inches deep with a Mack weed gun at varying rates and spacings in tilled and untilled soil under several moisture conditions. Plots were 25 or 100 square feet. One control plot was used with each experiment.

Field Dosage Test. For tests of dosage under field conditions, an area 10 feet wide and 60 feet long was divided into six equal squares. The area had been disked to a depth of 6 inches 6 weeks earlier and at that time two irrigation furrows about 4 inches deep had been laid out, running the length of the area. Irrigation water had been run down the furrows shortly after the disking; it settled the soil in the furrows and caused some crusting and compaction of the soil around the furrows. The soil below 6 inches in depth was compact.

CBP formulation was applied at rates of $0,10,20,40,80$, and 160 gallons per acre. Injections were made on a square pattern of 12 -inch spacing. In making applications at the lower rates ( 10 to 80 gallons per acre) it was found convenient to dilute the CBP formulation with cleaning solvent (naphtha) to secure sufficient volume for effective functioning of the applicator. Tests of the diluent alone failed to indicate measurable toxicity in the amounts used.

Five days after the fumigant was applied, the soil of a 2-square-foot area at the center of each plot was screened, and all tubers were placed in germi- 
nators. The per cent of viable tubers was determined for the top 6 inches and for the 6 to 12 inch depth.

Aerial growth of nutgrass was killed on all treated plots in the first 2 days after injection of the fumigant. However, living tubers were found in the soil in all plots except the one treated at the 160-gallon rate (table 2). In the 2 months after treatment there was extensive regrowth on the plots treated with 10 and 20 gallons. Regrowth after the 40-gallon treatment was sparse with the exception of the compacted furrows, where luxuriant growth occurred. Growth on the 80 -gallon plot was limited to a sparse stand in the irrigated furrows. No regrowth followed the 160-gallon treatment.

TABLE 3

PERCENTAGE OF NUTGRASS 'TUBERS SURVIVING FIELD TREATMENT WITH CBP FORMULATION IN UNTILLED SOIL CONTAINING VARYING AMOUNTS OF MOISTURE

Fumigant Injected to 8-inch Depth at 12-inch Spacings; Applied at the Rate of 80 Gallons per Acre

\begin{tabular}{|c|c|c|c|c|}
\hline \multirow[b]{2}{*}{ Per cent soil moisture } & \multicolumn{2}{|c|}{ In $0-6$ inch depth } & \multicolumn{2}{|c|}{ In 6-12 inch depth } \\
\hline & $\begin{array}{c}\text { Total } \\
\text { tubers }\end{array}$ & $\begin{array}{l}\text { Per cent } \\
\text { of tubers } \\
\text { surviving }\end{array}$ & $\begin{array}{l}\text { Total } \\
\text { tubers }\end{array}$ & $\begin{array}{l}\text { Per cent } \\
\text { of tubers } \\
\text { surviving }\end{array}$ \\
\hline 2.05 & 91 & 7 & 35 & 0 \\
\hline 3.19 . & 193 & 10 & 39 & 0 \\
\hline 3.27 . & 74 & 20 & 12 & 8 \\
\hline $5.62 \ldots$ & 96 & 7 & 132 & 0 \\
\hline $7.22 \ldots \ldots \ldots \ldots \ldots \ldots \ldots$ & 68 & 16 & 15 & 7 \\
\hline
\end{tabular}

Untilled Soil with Varying Soil Moisture. Another experiment in the same field was planned to take advantage of a variation in soil moisture without apparent difference in nutgrass population. Fumigations at the rate of 80 gallons per acre, with 12-inch injection spacings, were made to five plots each 5 feet square in an area of firm, untilled soil near an irrigation standpipe. Soil-moisture determinations made at the time of fumigation showed that the moisture varied from 2.0 to 7.2 per cent on the different plots. The field capacity of the soil was not determined. The compact untilled soil offered a further comparison with similar experiments, made on the same date, in well-tilled soil (see the next section).

Kill was incomplete in all plots without apparent correlation with soil moisture (table 3). A higher kill was attained in the layer 6 to 12 inches below the surface than in the upper 6 inches of soil.

Tilled Soil. In still another area in the same field the soil was loose and open to a depth of 6 inches as a result of recent tillage. At lower depths the soil was compact but without a pronounced plowsole. Four adjacent 25square-foot plots in this area were fumigated with CBP formulation at the rate of 80 gallons per acre in a square pattern of injections spaced $6,8,10$, and 12 inches respectively. A control plot was not fumigated.

Two weeks after the fumigant was applied, tubers were screened out of 2 square feet of soil of each plot to a depth of 12 inches. Ninety-five tubers 
were recovered from the control, of which 39 were viable. The treated plots yielded an average of 108 tubers per sample, none of which had survived the fumigation.

These plots, located in the same field as those in the preceding experiment, afford an opportunity for comparing the effectiveness of the fumigant in an open, well-tilled soil and in a compact, untilled soil. Presumably the recent tillage accounts for the effectiveness of the fumigant under all conditions of injection spacings in the present experiment. CBP movement is severely restricted by soil compaction and resultant reduction of porosity in the same way as carbon bisulfide (Hagan, 1941; Hanneson, 1945; Hanneson, Raynor, and Crafts, 1945).

\section{DISCUSSION}

The concentration required for an assured kill of tubers under laboratory conditions is on the order of $0.04 \mathrm{ml}$ of CBP formulation per liter of confined space $(0.02 \mathrm{ml}$ per test) in fumigation flasks containing vermiculite, and approximately the same amount per liter of soil. Fumigation for prolonged periods is not required: maximum kill was obtained with 5 hours' fumigation. The effectiveness of the fumigant was largely independent of temperature but was reduced when soil moisture was at field capacity. Tubers are quickly killed without induction of dormancy.

On the basis of laboratory experiments, it is estimated that fumigation with about 13 gallons per acre-foot should be required for effective control of nutgrass under ideal conditions in the field. For fumigation to a depth of 2 feet a basic requirement of about 26 gallons must be applied plus an additional amount to compensate for wastage, soil compaction, and other deviations from ideal conditions.

Although exact doses for practical use have yet to be determined under field conditions, 80 gallons per acre proved to be effective with injection spacings of 6 to 12 inches on moderately dry, well-tilled soil; 160 gallons per acre was effective in a light soil tilled and irrigated 6 weeks before fumigation.

CBP promises to provide an effective means of spot treatment of small infestations of nutgrass. It gives an immediate kill of all vegetative parts and may be conveniently applied without the use of tarpaulins or other special equipment. 
Andrews, F. W.

\section{LITERATURE CITED}

1940a. The control of nut grass in the Sudan Gezira. Empire Jour. Exp. Agr. 8: 215-22. 1940b. A study of nutgrass (Cyperus rotundus L.) in the cotton soil of the Gezira. Ann. Bot. n. s. $4: 177-93$.

\section{ANONYMOUS}

1934. How to deal with nut grass. Agr. Gaz. N. S. Wales 45: 366.

1938. Nut grass eradication. Queensland Agr. Jour. 50 : 355-56.

Burgis, D. S.

1949. Control of nutgrass with 2,4-D. Market Growers Jour. 78 (8) : 9, 22.

1951. Nut grass control with 2,4-D. Southern Weed Conf. Proc. 4: 24-25. (Mimeo.)

Burgis, D. S., and E. L. SPENCER

1947. Herbicides give control of certain weeds in vegetable seedbeds. Market Growers Jour. $76(8): 13,49$.

CIFERRI, D.

1931. An international enquiry on the biological and artificial control measures of nut grass (Cyperus rotundus). Internatl. Rev. Agr. 22 (2) : M143-45.

CowarT, L. E., and T. C. RYKeR

1950. Studies on the control of nut grass (Cyperus rotundus). Southern Weed Conf. Proc. 3:135-39. (Mimeo.)

Davis, C. H., and R. S. Hawkins

1943. Eradication and control of nut grass. Arizona Agr. Exp. Sta. Bul. 189: 1-20.

From, F.

1942. The eradication of nut grass. Science $96: 337-38$.

GODFREY, G. H.

1939. The control of nut grass with chloropicrin. Soil Sci. 47: 391-95.

Hagan, R. M.

1941. Movement of carbon disulfide vapor in soils. Hilgardia 14: 83-118.

Hannesson, H. A.

1945. Movement of carbon disulfide vapor in soils as affected by soil type, moisture content and compaction. Hilgardia 16: 501-10.

Hannesson, H. A., R. N. Raynor, and A. S. Crafts

1945. Herbicidal use of carbon disulfide. California Agr. Exp. Sta. Bul. 693 : 1-57.

HARRISON, A. L.

1946. 2,4-D for the control of nut grass. Florida State Hort. Soc. Proc. 59 : 78-81.

Holland, T. H.

1925. Cora grass, Cyperus rotundus sinh. kalanduru. Tropical Agr. 65: 162-63.

LEONARD, O. A., and V. C. HARRIS

1950a. Methyl bromide eradicates nutgrass. Down to Earth 6 (1) : 13.

1950b. Nutgrass control with methyl bromide. Southern Weed. Conf. Proc. 3: 132-34. (Mimeo.)

MAYton, E. L., E. V. SMith, and Dale King

1945. Nutgrass eradication studies: IV. Use of chickens and geese in the control of nutgrass, Cyperus rotundus L. Amer. Soc. Agron. Jour. 37: 781-91.

Pollock, N. A. R.

1925. Eradication of nut grass. Queensland Agr. Jour. ser. 2, 23: 53-56.

RANADE, S. B., and W. BuRnS

1925. The eradication of Cyperus rotundus L. India Dept. Agr. Mem. 13: 99-192.

Smith, E. V., and E. L. MAYTON

1939. Nut grass eradication studies: II. The eradication of nut grass, Cyperus rotundus L., by certain tillage treatments. Amer. Soc. Agron. Jour. 30: 18-21.

1942. Nut grass eradication studies: III. The control of nut grass, Cyperus rotundus L., on several soil types by tillage. Amer. Soc. Agron. Jour. 34: 151-59.

SumMerville, W. A. T.

1933. Two insect enemies of nut grass. Queensland Agr. Jour. 40: 284-87. 
The journal Hilgardia is published at irregular intervals, in volumes of about 600 pages. The number of issues per volume varies.

Subscriptions are not sold. The periodical is sent as published only to libraries, or to institutions in foreign countries having publications to offer in exchange.

You may obtain a single copy of any issue free, as long as the supply lasts; please request by volume and issue number from:

\section{Publications Office \\ College of Agriculture \\ Berkeley 4, California}

The limit to nonresidents of California is 10 separate issues on a single order. A list of the issues still available will be sent on request.

In order that the information in our publications may be more intelligible it is sometimes necessary to use trade names of products or equipment rather than complicated descriptive or chemical identifications. In so doing it is unavoidable in some cases that similar products which are on the market under other trade names may not be cited. No endorsement of named products is intended nor is criticism implied of similar products which are not mentioned. 